\title{
NON GENETEC PARAMETERS AND REPEATABILITY FOR MILK TRAITS GOAT IN NORTHERN IRAQ
}

\author{
Mevan I. Baper ${ }^{\text {a } *}$, Hani N. Hermiz ${ }^{b}$ \\ a Dept. of Animal Production, Akre Technical College, Duhok Polytechnic University, Kurdistan Region, Iraq (mevan.ibrahim@dpu.edu.krd) \\ ${ }^{\mathrm{b}}$ Dept. of Animal Production, College of Agriculture, University of Salahaddin, Kurdistan Region, Iraq (profdrhani59@gmail.com)
}

Received: Jul, 2019 / Accepted: Sept., 2019 / Published: Sept.,2019

https://doi.org/10.25271/sjuoz.2019.7.3.612

\begin{abstract}
:
A total of 439, 436 and 437 records of average daily milk yield (ADMY), milk yield after weaning (MYAW) and total milk yield (TMY) respectively were analyzed. Data used in this study obtained from mountain does at private project in Raselain Village/ Akre Region/ Duhok governorate. The data related to two milking seasons (2016-2017) and (2017-2018). The animals were allowed to graze natural pasture and stubble, straw and ground oak acorns were providing whenever required. Does were flushed 2 weeks prior to mating and kidding season. The flock was placed on a regular health program. Does were milked by hand at biweekly intervals starting from the first week post kidding till the does are dried off. ADMY was calculated by multiplying test day milk yield * 2. While TMY calculated by multiplying ADMY by lactation period. Statistical analysis of data was carried out by using GLM procedure within SAS programme. This model includes effects of doe's age, year and season of kidding, birth's type and sex and weight of doe at kidding on milk traits. Effect of doe added to above model as a random effect to estimate their repeatability using Restricted Maximum Likelihood method. Overall means for ADMY, MYAW and TMY were 0.727, 54.49 and $129.32 \mathrm{~kg}$ respectively. Results showed that the age of does had significantly higher effect $(\mathrm{P}<0.01)$ on all studied traits of milk. Does aged 4.5 years produce significantly higher ADMY $(0.772 \mathrm{~kg})$, and accordingly TMY $(136.88 \mathrm{~kg})$, while higher MYAW recorded for does aged 3.5 years beside 4.5 years. The effectiveness of year was significant $(\mathrm{P}<0.01)$ on all milk yield traits. Also season of kidding affect all studied milk traits significantly $(\mathrm{P}<0.01)$, whereas the does kidding in winter had significantly higher ADMY, MYAW and TMY than those kidding in spring season. The effects of type of birth and sex of kids were significant on all milk traits. Does with female twins produced significantly more ADMY comparing with does having male or female singles only. Does with female twins and male and female twins produced significantly much MYAW. Does with female twins yield significantly higher TMY when compared to those in the other groups, on the same time there were no significant differences in TMY of does with male twin and does with male and female twin. There was no significant effect of doe weight at kidding on all studied traits and the regression coefficients were positive for ADMY $(0.0003 \mathrm{~kg} / \mathrm{kg})$, and TMY $(0.085 \mathrm{~kg} / \mathrm{kg})$ while the regression was negative for MYAW (- $0.0024 \mathrm{~kg} / \mathrm{kg})$. Repeatability estimates of ADMY, MYAW and TMY were $0.24,0.31$ and 0.27 respectively. It sum: due to the effectiveness of the fixed factors on the studied traits, hence adjusting records is necessary. The estimates of repeatability indicate that selection of does as well their kids depending on their milk production will improve the productivity in the next year.
\end{abstract}

KEYWORDS: Mountain Goat, Milk Traits, Genetic Non-Genetic Effects, Repeatability.

\section{INTRODUCTION}

Goat is widespread cosmopolitan due to its nutritional and environmental adaptability and it is one of the domesticated small ruminants as well has served humans far than cattle or sheep (Mirzaei, 2011).

A goat population in Iraq estimated to be approximately 1.5 million heads, which again depends on cereal by-products and extensive pastures for feeding which is linked closely to the grazing patterns of other ruminants (FAO, 2014), as well the goat considered an important livestock in Iraq and has a significant function for the meat and milk products, especially under the systems of agriculture surviving in the country (Alkass and Juma, 2005). In many developed countries the goat's milk production is significantly important to the economy and survival (Haenlein, 2004). Fahim et al. (2013) stated that goats come in livestock as milk, meat, skin and hair. Moreover, the milk of goat is different from the milk of cow or human in higher digestibility, alkalinity, the capacity of higher buffering with certain value in medicine and nutritional of human (Park, 1994).

It is stated that local goat genotype could produce adequate milk and support growth of kids without supplement of feeding if the genotype are suited to environment condition (Cabiddu et al., 1999 and Sangare and Pandey, 2000). Goat have been reported to be more efficient milk producer than sheep, livestock and buffaloes based on their body live weight (Malau-aduli et al., 2001 and Ozung et al., 2011), because of better feed utilization efficiency, higher lactation persistency, mammary tissue comprising of greater proportion of the body weight and a more pronounced milk ejection reflex therefore, there is a need to look into the milk production potentials of goats as it relates to yield. Also, Rai et al. (2001) reported that milk production is an important feature of Mountain breed of goat which is necessary for the survival of the kids as well as provides nutrition to the goat keeper, and this is the same finding in Kurdistan region of northern Iraq depending on the results found in this study. Goats could produce much milk greater than which reported in the official statistic due to the large number of unreported

* Corresponding author

This is an open access under a CC BY-NC-SA 4.0 license (https://creativecommons.org/licenses/by-nc-sa/4.0/) 
home consumption in developing countries (Hayam et al., 2014)

Improvement of milk production in goats can arise through improvement in management, feeding regimes and through genetic improvement by selecting animals with higher genetic merit than average to be parents of the next generation, such that the average genetic merit of their progeny will be higher than the average of the parental generation (Singh and Acharya, 1982; Cameron, 1997 and Hermiz, 2001). Achieving this improvement will require to adjust the records of all data available for the non-genetic influences and take into account the heritability and repeatability of interested trait(s) as well the contribution rate of each individual in the stock, through the relationship matrix (Das et al., 1996; Freeman, 1998; Sakul et al., 1999 and Schaeffer, 2001). The accuracy of genetic evaluation of animals can be improved by evaluating animals under standard environmental conditions (Hermiz, 1998).

The aims of this study are to analyze non-genetic parameters and repeatability for milk traits of Mountain goat in local flock raised at Akre, Kurdistan Region, and to estimate the genetic parameters using an accurate method to be able to improve their productivity by breeding beside the suitable management.

\section{MATERIALS AND METHODS}

Data used in this study obtained from mountain does at private project in Raselain Village/ Akre Region/ Duhok governorate. The data related to two milking season (20162017) and (2017-2018). A total of 439, 436 and 437 records of average daily milk yield (ADMY), milk yield after weaning (MYAW) and total milk yield (TMY) respectively were analyzed. The animals were allowed to graze natural pasture and stubble, straw and ground oak acorns (Quercus aegilops) were providing whenever required. Does were flushed 2 weeks prior to mating season and 2 week prior to the kidding season. While the bucks were isolated from flock and flushed 4 week prior to mating season. The flock was placed on a regular health program including vaccination, drenching and dipping. Does were milked by hand at biweekly intervals starting from the first week post kidding till the does are dried off (less than $100 \mathrm{~g}$ ), kids were separated from their dams overnight (at 8:00 pm - 8:00 am) prior to milking. Average daily milk yield was calculated by multiplying test day milk yield * 2 (ICAR, 1995). While the total milk yield was calculated by multiplying test day milk yield by lactation period.

The statistical analyses of data were carried out by using General Linear Model (GLM) procedure within the statistical programme SAS (2005), the following model was used to analyze the studied traits including ADMY, MYAW and TMY:

$\mathrm{Y}_{\mathrm{ijklmn}}=\mu+\mathrm{A}_{\mathrm{i}}+\mathrm{R}_{\mathrm{j}}+\mathrm{S}_{\mathrm{k}}+\mathrm{T}_{\mathrm{l}}+\mathrm{b}_{\mathrm{m}}+\mathrm{e}_{\mathrm{ijklmn}}$

Where

$\mathrm{Y}_{\mathrm{ijklmn}}$ : measurements on $\mathrm{n}^{\text {th }}$ observation;

$\mu$ : overall mean;

$\mathrm{A}_{\mathrm{i}}$ : effect of $\mathrm{i}^{\text {th }}$ age of doe (where, $\mathrm{i}=2.5,3.5,4.5,5.5$ year);

$\mathrm{R}_{\mathrm{j}}$ : effect of $\mathrm{j}^{\text {th }}$ year of kidding (where, $\mathrm{j}=2016-2017,2017$ 2018);

$\mathrm{S}_{\mathrm{k}}$ : effect of $\mathrm{k}^{\text {th }}$ season of kidding (where, $\mathrm{k}=$ winter, spring);

$T_{1}$ : effect of $1^{\text {th }}$ birth's type and sex of kid (where, $1=$ female twin, male twin, male and female twin, male single, female single);

$b_{m}$ : effect of the regression of doe weight at kidding;

e $\mathrm{ejklmn}_{\mathrm{j}}$ : random error NID $\left(0, \mathrm{I}^{2} \mathrm{e}\right)$.
Restricted Maximum Likelihood-REML (Patterson and Thompson, 1971) method used to estimate the variance component of random effects. The effect of doe was added to the above model as a random effect in order to estimate the repeatability of the studied traits.

\section{RESULTS AND DISCUSSION}

Overall means for ADMY, MYAW and TMY were $0.727 \pm$ $0.004,54.49 \pm 0.39$ and $129.32 \pm 0.71 \mathrm{~kg}$ respectively (Table 1). Results attained in the current study are higher values than those of Iraqi local goat and their crosses with Damascus and Saanen bred in the middle of Iraq (Hermiz et al., 2004). While these findings were lower than those recorded earlier in Shami does bred in Erbil, Northern Iraq (Hermiz et al., 2015). Also TMY recorded in this study is lower than that of Damascus goat $(214 \mathrm{~kg})$ found by Mavrogenis et al. (1989) and that of native black does $(136.78 \mathrm{~kg}$ ) raised in Sulaimani - Northern of Iraq (Maarof et al., 2009). Such variation can be characteristic to a mixture of animal performance influencing genetic and environmental factors.

Results listed in first and second tables showed that the age of does had significantly higher effect $(\mathrm{P}<0.01)$ on all studied traits of milk. Does aged 4.5 years produce significantly higher ADMY $(0.772 \mathrm{~kg})$, and accordingly TMY $(136.88 \mathrm{~kg})$, while higher MYAW recorded for does aged 3.5 years beside 4.5 years comparing to does with other ages. Several Studies showed that the age of the dam is consider one the important factors that affecting the test day and total milk production. (Al-Azawi et al., 2015 and ALDabbagh and Oramari; 2016) indicated that dam at 3 to 4 years of age produce higher milk than other ages, while other studies indicated that dams at their 5 years of age produce much milk comparing to other age (Jawasreh, 2003; Toplu and Altinel, 2008 and Alkass and Merkhan, 2011). This because of the size of udder is larger of surrounding, teat distance, the length and the width (Alkass and Merkhan 2011). Such results resemble to earlier investigators who reported significant effect of doe's age on ADMY, MYAW and TMY (Alkass and Merkhan, 2011; Ibnelbachyr et al., 2015; AL -Dabbagh and Oramari, 2016 and Atay and Gokdal, 2016). While Hermiz et al. (1998, 2004 and 2015) didn't reveal to the significant effects for age of doe on their milk production. Hermiz (2001) claimed that milk production increase till the third or fourth season then decline. This effect could be due to maturity and development of digestive system and increase feed consumption (Randy et al., 1988).

The effectiveness of year was significant $(P<0.01)$ during kidding on all milk yield traits. The significant effect of year of kidding on ADMY, MYAW and TMY were in compatible with those reported earlier in Local and Damascus breeds (Crepaldi et al., 1999; Kominakis et al., 2000; Hermiz, 2001; Ishag et al., 2011 and Bedhane et al., 2012). This significant effect reflects the differences in management systems as well as the feeding of goats that vary due to environmental conditions from year to year (Crepaldi et al., 1999). Also season of kidding affect all studied milk traits significantly $(\mathrm{P}<0.01)$, whereas the does kidding in winter had significantly higher ADMY, MYAW and TMY than those kidding in spring season. In Iraq, the goats that kidded in the season of winter have significantly higher in both production of total milk and post-weaning milk yield than goat that kidded in the season of spring, while the variation between two seasons for test day milk production were nonsignificant (Hermiz et al., 1998). First and second tables reveals that kidding of does in season of winter had significantly higher ADMY, MYAW and TMY than kidding of does in the season of spring. Similar results were found 
by Blackburn and Field 1990, Hermiz et al. (1998), Kominakis et al. (2000), Hermiz et al., (2004), Mioc et al. (2008) and Taher (2017). Hermiz et al. (2015) revealed that kidding of does in winter had higher significantly $(\mathrm{P}<0.01)$ MYAW and TMY than does kidding in season of autumn, whereas the differences between the two seasons for ADMY were not significant. The year and season of kidding were significant effects on traits of milk reflect the environmental differences as well as the changes in management and feeding practices.

It appears from the results given in Table (2) that the effects of type of birth and sex of kids were significant on all milk traits. However table 1 represent that does with female twins produced significantly more ADMY comparing with does having male or female singles only. It was found that does with female twins and male and female twins produced significantly much MYAW than other groups. It was noticed that does with female twins yield significantly higher TMY when compared to those in the other groups, on the same time there were no significant differences in TMY of does with male twin and does with male and female twin. Such results resemble earlier reports significant effect on ADMY (Crepaldi et al., 1999; Kominakis et al., 2000 and Singh et al., 2000), MYAW (Louda and Doney, 1976) and TMY (Gokhale et al., 1997 and Sangare and Pandey, 2000). Hayden et al. (1979) stated that greater production of milk in goats with two or more kids can be demonstrated by increased level of placental lactogen in goats having multiple kids. Later, Hermiz et al. (2015) stated that does with triple births produce higher TMY and AVDM than those born single or twin kids. In Iraq, Hermiz et al. (1998) and (2004) appeared that sex effect by liter size on the traits of milk yield was non-significant. Also in India, Singh et al. (2009) noticed a non-significant effect of type of kidding on milk production and reproduction traits in Jamunapari goats.There was no significant effect of doe weight at kidding on all studied traits and the regression coefficients were positive for ADMY $(0.0003 \mathrm{~kg} / \mathrm{kg})$, and TMY $(0.085$ $\mathrm{kg} / \mathrm{kg}$ ) while the regression was negative for MYAW ($0.0024 \mathrm{~kg} / \mathrm{kg}$ ), which indicate that increasing $1 \mathrm{~kg}$ in body weight of doe at kidding will increase ADMY and TMY by 0.0003 and $0.085 \mathrm{~kg}$ respectively, and decrease MYAW by $0.0024 \mathrm{~kg}$ (Tables 1 and 2). Also Hermiz et al. (1998 and 2015) reported similar results in the non-significant effect. While other studies reported that the regression of milk traits on doe weight was significant (Mellado et al., 1991; Sangare and Pandey, 2000 and Hermiz et al., 2004).

Repeatability estimates obtained from this study of ADMY (0.24), MYAW (0.31) and TMY (0.27) were lower than estimated value mentioned earlier of traits of milk by using Local, Damascus and cross breed of goat in Iraq (Hermiz el al., 2004). Such estimates indicate that selection will increase future milk yield of the flock. In general these estimates were within the range of those reported earlier (Ilahi et al., 1998 and Ribeiro et al., 1998).

Table 1. Least square means \pm standard errors for the effects on milk traits $(\mathrm{kg})$ in Local Goat.

\begin{tabular}{|c|c|c|c|c|c|c|}
\hline \multirow{2}{*}{ Factors } & \multicolumn{2}{|c|}{ Average daily Milk Yield (kg) } & Milk Yield After Weaning $(\mathrm{kg})$ & \multicolumn{3}{|c|}{ Total Milk Yield (kg) } \\
\cline { 2 - 7 } & No & Means \pm S.E. & No & Means \pm S.E. & No & Means \pm S.E. \\
\hline Overall mean & 439 & $0.727 \pm 0.004$ & 436 & $54.49 \pm 0.39$ & 437 & $129.32 \pm 0.71$ \\
\hline Age of doe (years): & & & & & & \\
\hline 2.5 & 53 & $0.705 \pm 0.013 \mathrm{c}$ & 53 & $50.78 \pm 1.37 \mathrm{~b}$ & 53 & $124.75 \pm 2.51 \mathrm{c}$ \\
\hline 3.5 & 137 & $0.750 \pm 0.009 \mathrm{~b}$ & 135 & $55.91 \pm 0.98 \mathrm{a}$ & 136 & $133.65 \pm 1.79 \mathrm{~b}$ \\
\hline 4.5 & 169 & $0.772 \pm 0.009 \mathrm{a}$ & 169 & $56.46 \pm 0.96 \mathrm{a}$ & 169 & $136.88 \pm 1.77 \mathrm{a}$ \\
\hline 5.5 & 80 & $0.699 \pm 0.012 \mathrm{c}$ & 79 & $51.99 \pm 1.21 \mathrm{~b}$ & 79 & $124.54 \pm 2.23 \mathrm{c}$ \\
\hline Year of kidding: & & & & & & \\
\hline $2016-2017$ & 182 & $0.701 \pm 0.010 \mathrm{~b}$ & 180 & $49.98 \pm 1.00 \mathrm{~b}$ & 181 & $124.73 \pm 1.84 \mathrm{~b}$ \\
\hline $2017-2018$ & 257 & $0.761 \pm 0.097 \mathrm{a}$ & 256 & $57.59 \pm 0.98 \mathrm{a}$ & 256 & $135.17 \pm 1.82 \mathrm{a}$ \\
\hline Season of kidding: & & & & & & \\
\hline Winter & 356 & $0.750 \pm 0.008 \mathrm{a}$ & 354 & $56.04 \pm 0.86 \mathrm{a}$ & 355 & $133.72 \pm 1.58 \mathrm{a}$ \\
\hline Spring & 83 & $0.713 \pm 0.011 \mathrm{~b}$ & 82 & $51.54 \pm 1.10 \mathrm{~b}$ & 82 & $126.19 \pm 2.03 \mathrm{~b}$ \\
\hline Type of birth and Sex of Kids & & & & & & \\
\hline Female Twin & 8 & $0.785 \pm 0.024 \mathrm{a}$ & 8 & $59.45 \pm 2.46 \mathrm{a}$ & 8 & $140.71 \pm 4.52 \mathrm{a}$ \\
\hline Male Twin & 7 & $0.745 \pm 0.026 \mathrm{ab}$ & 7 & $51.62 \pm 2.61 \mathrm{~b}$ & 7 & $132.41 \pm 4.80 \mathrm{~b}$ \\
\hline Male and Female Twin & 13 & $0.738 \pm 0.019 \mathrm{ab}$ & 13 & $55.65 \pm 1.93 \mathrm{a}$ & 13 & $130.41 \pm 3.54 \mathrm{~b}$ \\
\hline Male Single & 215 & $0.701 \pm 0.005 \mathrm{~b}$ & 213 & $51.51 \pm 0.56 \mathrm{~b}$ & 214 & $124.34 \pm 1.03 \mathrm{c}$ \\
\hline Female Single & 196 & $0.688 \pm 0.006 \mathrm{c}$ & 195 & $50.70 \pm 0.58 \mathrm{~b}$ & 195 & $121.89 \pm 1.07 \mathrm{~d}$ \\
\hline Regression on Doe weight at kidding & 439 & $0.0003 \pm 0.0001$ & 436 & $-0.0024 \pm 0.001$ & 437 & $0.085 \pm 0.014$ \\
\hline
\end{tabular}

Means having different letters within each factor/column differ significantly $(\mathrm{P}<0.01)$ according to Schaffer's test.

Table 2. Mean squares and test of significance for factors affecting milk traits in Local goats.

\begin{tabular}{|l|c|c|c|c|c|c|}
\hline \multirow{2}{*}{ Factors } & \multicolumn{2}{|c|}{$\begin{array}{c}\text { Average daily Milk Yield } \\
(\mathrm{kg})\end{array}$} & \multicolumn{2}{|c|}{ Milk Yield After Weaning (kg) } & \multicolumn{2}{c|}{ Total Milk Yield (kg) } \\
\cline { 2 - 6 } & d.f. & Mean squares & d.f. & Mean squares & d.f. & Mean squares \\
\hline Age of doe (years) & 3 & $0.1178^{* *}$ & 3 & $631.765 * *$ & 3 & $3544.317 * *$ \\
\hline Year of kidding & 1 & $0.2055^{* *}$ & 1 & $3301.26^{* *}$ & 1 & $6215.451^{* *}$ \\
\hline Season of kidding & 1 & $0.0829 * *$ & 1 & $1232.88^{* *}$ & 1 & $3454.48^{* *}$ \\
\hline Type of birth and sex of kids & 4 & $0.0289 * *$ & 4 & $208.981 * *$ & 4 & $1012.244 * *$ \\
\hline $\begin{array}{l}\text { Regression on Doe weight at } \\
\text { kidding }\end{array}$ & 1 & 0.0008 & 1 & 0.0423 & 1 & 51.449 \\
\hline Residual & 428 & 0.0045 & 425 & 46.016 & 426 & 155.484 \\
\hline
\end{tabular}

$* *=\mathrm{P}<0.01$ 


\section{CONCLUSION}

In sum: due to the effectiveness of the fixed factors on the studied traits, hence adjusting records is necessary. The estimates of repeatability indicate that selection of does as well their kids depending on their milk production will improve the productivity in the next year.

\section{REFERENCES}

AL-Azawi, Z.M.M., Said, S.I., \& Nida, S.M. (2015). Factors affecting in milk composition in Cyprus, Local goats and their cross. Journal of Kerbala for Agricultural Sciences.Vol. 2 (4): 76-87.

AL-Dabbagh, A.S.H.S., \& Oramari, R.A.S. (2016). A comparative study on milk yield and its composition between Black mountain and Damascus (Shami) goats raised at commercial farms. The 2nd Scientific Agricultural Conference (April 26 and 27th 2016). J. Univ. Duhok.19 (1): 94-101.

Alkass, J.E., \& Juma, K.H. (2005). Small Ruminant Breeds of Iraq. (Edi. Lusi Iniguez). Characterization of small Ruminant Breeds in West Asia and North Africa. ICARDA (International Center of Agriculture Research in the Dry Areas).

Alkass, J.E., \& Merkhan, K.Y. (2011). Milk production traits of indigenous Black and Meriz goats raised under farm production system. Res. Opin. Anim. Vet. Sci., 1(11): 708-713.

Atay, O., \& Gokdal, Ö. (2016). Some production traits and phenotypic relationships between udder and production traits of Hair goats. Indian Journal of Animal Research, 50: 983-988

Bedhane, M., Haile, A., Dadi, H., \& Tesfaye, A.T. (2012). Estimates of genetic and phenotypic parameters for milk traits in Arsi-Bale goat in Ethiopia. Livestock research for rural development 24 (6) 2012.

Blackburn, H.D., \& Field, C.R. (1990). Performance of Somali Blackhead sheep and Galla goats in northern Kenya. Small, Rumin. Res., 3: 539-549.

Cabiddu, A., Branca, A., Decandia, M., Pes, A., Santucci, P.M., Masoero, F., \& Calamari, L. (1999). Relationship between body condition score, metabolic profile, milk yield and milk composition in goats browsing a mediterranean shrubland. Livestock Production Science 61, 267-273.

Cameron, N.D. (1997). Selection indices and prediction of genetic merit in animal breeding. CAB international. 1St edition. Edinburgh, UK

Crepaldi, P., Corti, M., \& Cicogna, M. (1999). Factors affecting milk production and prolificacy of Alpine goats in Lombardy (Italy). Small, Rumin. Res., 32: 83-88.

Das, S.M., Rege, J.E.O. \& Shibre, M. (1996). Phenotypic and genetic parameters of growth traits of Blended goats at Malya, Tanzania. Proceeding of the third biennial conference of the African Small Ruminant Research Network. ILRI. p: 63-70 . Nairobi, Kenya.

Fahim, A., Patel, B.H.M., \& Rijasnaz, V.V. (2013). Relationship of body weight with linear body measurements in Rohilkhand local goats. Indian Journal of Animal Research. 47 (6) 521-526.

FAO (Food and Agriculture Organization) (2014). Global information and early warning system on food and agriculture (GIEWS) Special Alert. Available at http://www.fao.org. No. 332- IRAQ. [Verified June 2014].

Freeman, A.E. (1998). Dairy cattle breeding. 6th World Congress on Genetics Applied to Livestock Production. 12-16, Jan. Armidale, NSW Australia. 23: 293-294.

Gokhale, S.B., Rathor, B.G., Wadher, M.H., Sharma, M.S., \& Rangnekar, D.V. (1997). Effect of non-genetic factors on milk production of rural goats. Indian J Anim Sci. 67: 698-702.

Haenlein, G.F.H. (2004). Goat milk in human nutrition. Small Ruminant Res., 51, 155-163.

Hayam, M.A., Fatma, A.M., Hassan, M.A.M., El-Gawad, A., \& Enab, A.K. (2014). Physicochemical characteristics of Goat's milk. Life Sci J 11: 307-317.)
Hayden, T.J., Thomas, C.R., \& Forsyth, I.A. (1979). Effect of number of young born (litter size) on milk yield of goats: role for placental lactogen. J. Dairy Sci., 62: 53-57.

Hermiz, H.N. (1998). Additive and multiplicative adjustment factors for milk traits in Iraqi local goat. Iraqi J. Agric., 3(2): 164-173.

Hermiz, H.N., Asofi, M.K., \& Al-Rawi, A.A. (1998). Some genetic and non-genetic causes of variation variation in milk traits of Iraqi local goat. 6th world congress on genetics applied to livestock production. 12-16, Jan. Armidale, NSW Australia. 24: 212-215.

Hermiz, H.N. (2001). Genetic evaluation of Local goats and their crosses using some productive traits. Ph.D. thesis, College of Agriculture, University of Baghdad. (Arabic).

Hermiz, H.N., Singh, M., Al-Rawi, A.A., \& Alkass, J.E. (2004). Genetic and non-genetic parameters for milk traits in Iraqi local goat and their crosses. Dirasat, Agricultural sciences, 31 (2): 223-228.

Hermiz, H.N., Ahmed, A.M., Hamad, D.A., Al-Khatib, T.R., \& Amin, Sh.M. (2015). Non-genetic effects and prediction equations for milk traits of shami ewes in Erbil-KRGIRAQ. Proceedings of the IRES 10th International Conference, Prague, Czech Republic, 27th September. 2015, ISBN: 978-93-82702-05-4, pp: 1-6.

Ibnelbachyr, M., Boujenane, I., Chikhi, A. \& Noutfia, Y. (2015). Effect of some non-genetic factors on milk yield and composition of Draa indigenous goats under an intensive system of three kiddings in 2years. Trop. Anim. Health. Prod. 47 (3).

ICAR (1995). International committee for animal recording. International regulations for milk recording in sheep. Institute de I'Elevage: Paris.

Ilahi, H., Chastin, P., Martin, J., Monod, F., \& Manfredi, E. (1998). Genetic association between milking speed and milk production. 6th World Congress on Genetics Applied to Livestock Production. 12-16, Jan. Armidale, NSW Australia. 24: 216-219.

Ishag, I.A., Abdalla, S.A. \& Ahmed, M.K.A. (2011). Factors affecting milk production traits of Saanen goat raised under Sudan-semi arid conditions. Online Journal of Animal and Feed Research, 1 (5): 435-438.

Jawasreh, K.I. (2003). Genetic evaluation of Damascus Goats in Jordan. Ph.D.Thesis, College of Agriculture, University of Bagdad, Iraq

Kominakis, A., Rogdakis, E., Vasiloudis, Ch. \& Liaskos, O. (2000). Genetic and environmental sources of variation of milk yield of skopelos dairy goats. Small Rumin. Res., 36: 15 .

Louda, F., \& Doney, J.M. (1976). Persistency of lactation in the Improved Valachian breed of sheep. J. agric. Sci., Camb., 87:455-457.

Maarof, N.N., Hermiz, H.N., Salih, N.G., \& Alkass, J.E. (2009). Prediction of total milk yield from partial monthly yield in Native Black Goats. J. Zankoy Sulaimani. 12(1) part (A): 1-5.

Malau-Aduli, B.S., Eduvie, I.O., Lakpini, C.A.M., \& Malau-Aduli, A.E.O. (2001). Effect of Supplementation on the Milk Yield of Red Sokoto Does. Proceedings of the 26th Annual Conference of Nigerian Society of Animal Production, March 21-25, 2001, ABU, Zaria: Nigeria pp: 353-355.

Mavrogenis, A.P., Papachristoforou, C., Lysandrides, P., \& Roushias, A. (1989). Environmental and genetic effects on udder characteristics and milk production in Damascus goats. Small Rumin. Res., 2: 333-343.

Mellado, M., Foote, R.H., \& Borrego, E. (1991). Lactational performance, prolificacy and relationship to parity and body weight in crossbred native goats in northern Mexico. Small Rumin. Res., 6: 167-174.

Mioc, B., Prpic, Z., Vnuce, I., Baeac, Z., Sustic, V., Samarziji, D., \& Pavic, V. (2008). Factors affecting goat milk yield and composition. Mljekarstvo 58: 305-313.

Mirzaei, F. (2011). Effect of herbal feed additives on performance parameters of ruminants and especially on dairy goats; a Review. IJAVMS 3: 18-36.

Ozung, P.O., Nsa, E.E., Ebegbulem, V.N., \& Ubua, J.A. (2011). The Potentials of Small Ruminant Production in Cross River Rain Forest Zone of Nigeria: A Review. Conti J Anim Vet Res 3: 33-37). 
Park, Y.W. (1994). Hypo-Allergenic and Herapeutic significance of Goat Milk. Small Ruminant Res 14: 151-159.

Patterson, H.D., \& Thompson, R., 1971. Recovery of interblock information when block sizes are unequal. Biometrika, 58:545-554.

Rai, B., Khan, R.U., \& Yadav, M.C. (2001).Genetic and phenotypic parameters of milk production traits in Marwari goats. Indian J. Anim. Sci. 71:177-179.

Randy, H.A., Sniffen, C.J., \& Heintz, J.F. (1988). Effect of age and stage of lactation on dry matter intake and milk production in Alpine does. Small Rumin. Res., 1: 145154.

Ribeiro, A.C., Queiroz, S.A., Lui, J.F., Ribeiro, S.D.A., \& Resende, K.T. (1998). Genetic and phenotypic parameters estimates and genetic trend of milk yield of Saanen goats in Southeast of Brazil. 6th World Congress on Genetics Applied to Livestock Production. 12-16, Jan. Armidale, NSW Australia. 24: 234-237.

Sakul, H., Boylan, W.J., \& Shrestha, J.N.B. (1999). Animal model evaluation of dairy traits in US sheep breeds, their crosses and three synthetic populations. Small Rumin. Res., 34:1-9.

Sangare, M., \& Pandey, V.S. (2000). Food intake, milk production and growth of kids of local, multipurpose goats grazing on dry season natural Sahelian rangeland in Mali. Animal Science 71, 165-173.

SAS (2005). SAS/STAT User's Guide for Personal Computers, Release 8.00.SAS Institute Inc., Cary, NC, USA

Schaeffer, L.R. (2001). Animal Models. http: //www. aps. uoguelph. ca/ Irs/ Animalz/ 10-637-last updated: Jan. 4, 2001. University of Guelph, Ontario.

Singh, D.K., Singh, C.S.P., Singh, N.S., \& Singh, L.B. (2000). Genetic analysis of milk production characteristic of Black Bengal and its halfbred. Indian Journal of Animal Sciences 70: 1167-69.

Singh, M.K., Rai, B., \& Singh, N.P. (2009). Genetic analysis of milk production traits of Jamunapari goats. Indian J. Anim. Sci. 79, 83-86.

Singh, R.N., \& Acharya, R.M. (1982). Genetic and environmental trends of milk production in a closed flock of Beetal goats. J. Dairy Sci., 65: 2015-2017.

Taher, M.T. (2017). Genetic and non-genetic parameters of some economic traits in Maraz Goats. M.Sc. Thesis, College of Agriculture, University of Duhok, Iraq.

Toplu, H.D.O., \& Altinel, A. (2008). Some production traits of indigenous hair goats bred under extensive conditions in turkey. 2nd communication: viability and growth performances of kids. Arch.Tierz.Dummertorf .51(5):507-514. 